\title{
An Islamic Perspective of Sex and Sexuality: A Lesson for Contemporary Muslim
}

\author{
Dr. Sikiru Gbenga Eniola \\ Department of Religious Studies Ekiti State University Ado-Ekiti, Nigeria
}

\begin{abstract}
This Paper sets to investigate the aspect of an Islamic perspective of sex and sexuality such as the goals of marriage, the practice of homosexuality, celibacy and monasticism. It also looks at the Islamic guidelines which could assist Muslims to uphold sexual morality such as faithful to one's wife or husband, proper dressing, early marriage, lowering of the gaze/ modesty and the concept of adultery. The methodology employed in this paper was based on information and analysis of the data from books, journals, archives, newspapers, reports, internet, the Holy Qur'an and Ahadith. The paper reveals that, Islam considers sex as one of the essential human needs that must be properly satisfied. It is a necessity of the human being that, it requires favourable consideration. Infact, Islam considers it as one of the requirements of life that should be properly and lawfully satisfied. Moreover, Islam does not treat it as distasteful, filthy or heinous act of man. It also, considers "Zina" not only as a great sin but also as an act, which opens the gate for many other shameful acts, which destroys the very basis of the family, leads to quarrels, murders, ruins reputation/ properties and also spreads numerous diseases, both physical and spiritual. It is recommended that, Muslim should marry as early as they are able. Muslims should not fear poverty nor should they apprehend increase of family members as a result of marriage, and thus, because of that, stay away from marriage.
\end{abstract}

\section{Introduction}

Islam's attitude towards sex may be understood and appreciated only if one makes a sincere effort to study the Glorious Qur'an and Ahadith. The Glorious Qur'an tells us that all that exist in this universe have been created in pairs as is evident from the following verse: "And of everything we have created in pairs so that you may receive instruction." (Qur'an, 51: 40)

Moreover, the Glorious Qur'an confirms that the primary objective for creating everything in pairs is to facilitate each species to procreate its own kind: "He has made for you pairs (mates) from among yourselves and pairs among cattle: By this does, He multiply you." (Qur'an, 42: 11) Islam, therefore, recognizes sex as a natural desire, but cautions that it is the institution of marriage which legitimizes the fulfillment of the sexual desire, which is otherwise forbidden. This is why both the Glorious Qur'an and Ahadith exhort Muslims to marry.

That is why Allah states in the holy Qur'an Chapter (3:14) as thus:

Fair in the eyes of men in the love of thing they covet: women and sons, heaped-up

hoards of gold and silver, horses branded (for blood and excellence); and (weather) cattle and well-tilled land. Such are the possession of this world's life; but in nearness to Allah is the best of the goals (to return to)

In addition, the Holy Prophet (SAW) is reported to have said: "Three items for this world were made attacked (or likeable) to me, women, perfume (but) the (utmost) pleasure of my eyes (soul) is in prayer". (Bukhar)

Infact, Islam forbids controlling and deprivation of the sexual behavior. This is simply because Islam is the natural religion commensurate to pure human innate. Islam does not, at any time, conflict with the requirements and desires of the human. Islam rather attempts to answer and fulfill all human needs and requirements. It does so by setting certain lawful limits and restrictions to ensure satisfying those needs in a right and lawful manner (Sulaiman, 2010, Shahid, 2003 and Sharubassy, 1974). Also, Islam endeavors to keep sex within the framework of human needs and elevates it above the savage and uncivilized way. This is in accordance to the Sayings of prophet Muhammad (SAW) which says:

People enter Janah, (paradise) mostly based on Taqwa of Allah (Full respect and obedience of the commandment of Allah and His messenger) and based on their good conduct. (While) most people enter the hellfire because of the (illuse) of the Mouth and private parts (Muslims).

But, the only acceptable way for sexual satisfaction in Islam is lawful marriage. Islam urges Muslim to seek Marriage and encourages them to practice it. This is in accordance with the message of Prophet (SAW) in which He says: "Whoever is financially capable of marriage but does not marry, he does not belong to me (that is, my follower)" (Muslim) 
Even though, if a male Muslim cannot afford to marry because of poverty, he is commanded to chastise himself as follows: " Let who find not the where withal for marriage keep themselves chaste, until give them means out of his Grace" (Q24:33)

Again, the Prophet (SAW) gives advice that make easier to certain extent for a person who is unable to marry for dearth of marriage expenses. The advice encourages his desire not to marry and enable him to control his sexual desire as follows:

Oh young man whoever is capable (financially and other wise) to (afford the expenses) of marriage, let him do so. (Marriage) helps one control his eye sight and chastise his private parts. But who can't afford the marriage expenses let him observe fast as it would cast as a protector for him (Bukhari, Chapter 2, no. 5060)

That is why Islam commands its followers to marry as early as they are able. Muslim should not fear poverty nor should they apprehend increase of family members as a result of marriage, and thus, because of that, stay away from marriage. This is contrary to the commandment of Almighty Allah in the holy Qur'an Chapter (24:32) which reads thus:

Marry those among you who are single, or the virtuous ones among your slaves male or female, if they are in poverty, Allah will give them means out of His Grace: for Allah encompass eth all, He Knowneth all things

Moreover the Prophet (SAW) is reported to have said that

Allah takes it upon Himself to help three types of people. These are: the warrior who is striving in the cause of Allah. A contracted slave, who wants to pay off the value set for his freedom of slavery and, a person, who seeks marriage to chastise himself. (Bukhar)

Likewise, the holy Qur'an further illustrated the best example of subduing the sexual drive in the story of Prophet Yusuf (Joseph) (AS) whose story set as one of the best examples for the Muslim youth as Allah states in the holy Qur'an chapter (12:23 - 24) which reads thus:

But she, in whose house he was, sought to seduce him from his (true) self: she fastened the doors, and said;" Now come, thou (dear one)' he said "Allah forbid! Truly (thy Husband) is My Lord He made the sojourn agreeable Truly, no good come to those who do wrong" and (with passion) did she desire him, and he would have rejected her, but that he saw the evidence of his Lord; thus ( did we order) that we might turn away from him (all) evil and shameful deeds: for he was one of our servants sincere and purify of the prestigious lady, the result of rejecting her request.

He over looked the adverse results stemming from his denial to the request for evil act was imprisonment According to the holy Qur'an Chapter (12:32 - 34).

"She said, "There before you is the man about whom ye did blame me! I did seek to seduce him from his (true) self but he did firmly save himself guiltless! And now, if he doth not my bidding, he shall certainly be cast into prison and (What is more) be of the campaign of the wiliest! He said: "O my Lord! The prison is more to my liking than that to do which they invite me: unless Thou turn away their snare from me, I should (in my youthful folly) feel inclined towards them and join the ranks of the ignorant". So his Lord hearkened to him (in his prayer) and turned away from him their shares. Verily He hearth and knowneth (all things)"

The Glorious Qur'an's imperative in this regard is: "Marry those among you who are single .... " (Qur'an, 24: 32)

Prophet Muhammad's (PBUH) advice to the young Muslims was:

Young men, those among you who can support a wife should marry. For it keeps you from looking (at strange women) and protects you from immorality (i.e., safeguards your chastity).( Al-Naysaburi, N.D, Hadith no. 1. Vol. 3. p. 546). Interestingly, the Glorious Qur'an stipulates with whom marriage is unlawful, thereby safeguarding Muslims from indulging in incest and other sexual crimes. They are as follows: (Qur'an, 22: 25)

(a) Fathers' wives; (b) Mothers; (c) Daughters; (d) Sisters; (e) Fathers' sisters; (f) Mothers' sisters; (g) Brothers' daughters; (h) Foster-mothers (i.e., "who gave you suck"); (i) Foster sisters; (j) Wives' mothers; (k) Stepdaughters under their guardianship (i.e. daughters of their wives under a previous marriage; (1) Those who have been wives of their sons; (m) Two sisters at one and the same time; (n) Women who are already married (i.e., already in wedlock with other husbands).

Furthermore, the Glorious Qur'an also limits the number of wives that one may have at one and the same time to four (Qur'an, 4: 3). This injunction is vital for it does in reality curb sexual excesses and perversions.

The goals of marriage based on the teachings of the Glorious Qur'an and the Hadith literature may be summarized as follows:

(a) Procreation of the human species, who may in turn worship Allah. 
(b) Generation of love, comfort and peace between husband and wife.

(c) Love for offspring. This love should eventually transcend and encompass all creatures so that each and every member of the human race develops a sense of belonging.

(d) Protection of loneliness. Family helps one to feel a sense of security in that there are other concerned members around to assist one to overcome one's difficulties.

(e) Entrenchment of responsibility.

Family life generates in every person the spirit of working collectively for the betterment of one's family members. This means that all major decisions are not to be taken in isolation, but in consultation.

\section{Fornication /Adultery}

In Islam, sexual intercourse between a man and a woman who are not married to each other is called "Zina" (Noibi, 2004 and Ogunlayi, 2003). It's immaterial whether one or both parties have their own spouses living, or are unmarried. It is also immaterial whether it is with the consent of the parties. The word "Zina" according to Doi, (1982) is applied to both Adultery (where one or both parties are married to a persons or persons other than the one involved in the sexual intercourse) and Fornication (where both parties are unmarried) (Sulaiman, 2006). Islam regards it in any case as a great sin as indicated in the Holy Qur'an as thus:

"Do not come near to adultery for it is a Shameful Deed and evil, opening the road to other evil. (Q17:32)

This verse considers "Zina" not only as a great sin but also as an act, which opens the gate for many other shameful acts, which destroys the very basis of the family and leads to quarrels and murders, which ruins reputation, properties and which also spreads numerous diseases, both physical and spiritual.

Yet, in another verse of the Holy Qur'an, Allah encourages Muslims to guard their private parts, by being chaste and loyal to one's sex partners so that one will not become blame worthy as follow:

"Successful indeed are the believers. Those who avoid vain talk, who are active in giving Zakat, who guard. Their modesty, except with those joined into them in the marriage bound, or (the captives) whom their right hands possesses, for (in their case they are free from blame, but those who desire except those limits are transgressors"(Q23:1-7)

The Muslims who are pious, God fearing and who keep away from all forms of indecencies by been faithful to their legitimate and loyally married sexual partners are those people who are able to prevent themselves from catching HIV/AIDS. Also, Allah warned the husband to keep away from all forms of disobedient wife as follow.

"Therefore, the righteous women are devotedly obedient, and guard in (the husband) absence what Allah would have them guard. As to those women on whose part ye fear disloyalty and ill-conduct, admonish them (first), (next), refuse to share there beds..."(Q 4:34)

From the above verses, it shows that Islam instructs the believer's purity and chastity, Islam further bestows on believers dignity and honours. The prophet also declared fornication or adultery to be the greatest evil after shirk that is associating partner with Allah as thus:

There is no sin after associating partners with Allah in the eyes of Allah than a drop of semen which a man places in the womb which is not lawful for him (Ahmed)

On the other hand, Islam direct its followers in the right direction by which they would be, Allah willing, morally, respectably and productive, However, the most interesting story is that of A young man who came to Prophet (SAW) and said

Please permit me to commit adultery. The companions of the prophet were enraged at these words, but the prophet Said to him, 'come, near to me young man, would you like any one to commit adultery with your mother?, the prophet asked, he replied, 'not at all' the prophet said the other people will also never tolerate such a shameful act with their mother 'then the prophet asked him the same question about his sister, wife and other relatives. Each time the youth answered "not at all" the prophet put his hand on his chest and prayed "O Allah! Purify his heart, forgive his sins and guard him against adultery (Athar-Shahid, 2003)

Also, Islam abhors adultery and enjoins Muslims to keep away from all those things that might prove to steps leading toward it. A passionate look at an unknown woman is the first of such step. The prophet in the following Hadith, prohibits thus:

"Even to look at an unknown woman with passionate eye) is also a sin". (Ahmed)

Also the prophet in the following words prohibits other steps towards adultery: 
The adultery of leg is walking (with bad intention towards a woman who is not lawful for a man) and the adultery of the hands is touching and pitting (such a woman) and the adultery of eye is casting passionate glances at her (Muslim)

In another hadith narrated Ibn Umar (RA), Allah's Messenger said,

Once three persons from the previous nations were traveling, and suddenly it started raining and they took shelter in a cave. The entrance of the cave got closed suddenly by the falling of a huge rock while they were inside. They said to each other, O You! Nothing can save you except the truth, so each of you should ask Allah's help by referring to such a deed as he thinks he did sincerely (i.e. just for gaining Allah's pleasure). So one of them said 'O Allah! You know that I had a laborer who worked for me for one faraq i.e. three SA of rice, but he departed, leaving it i.e. his wages. I sowed that faraq of rice and with its yield I bought cows for him. Later on when he came to me asking for his wages, I said to him, go to those cows and drive them away. He said to me, but you have to pay me only a Faraq of rice. I said to him, go to those cows and take them, for they are the product of that faraq of rice. So he drove them. O Allah! If you consider that I did that for fear of you, then please remove the rock. The rock shifted a bit from the mouth of the cave. The second one said, ' $\mathrm{O}$ Allah, You know that I had old parents whom I used to provide with the milk of my sheep every night. One night I was delayed and when I came, they had slept, while my wife and children were crying with hunger. I used not to let them i.e. my family drink unless my parents had drunk first. So I disliked waking them up and also disliked that they should sleep without drinking it, I kept on waiting for them to wake till it dawned. O Allah! If you consider that I did that for fear of You, then please remove the rock. So the rock shifted and they could see the sky through it. The third one said, 'O Allah! You know that I had a cousin i.e. my paternal uncle's daughter who was most beloved to me and I sought to seduce her, but she refused, unless I paid her one hundred dinars i.e. gold pieces. So I collected the amount and brought it to her, and she allowed me to sleep with her. But when I sat between her legs, she said: Be afraid of Allah, and do not deflower me but legally. I got up and left the hundred dinars for her. O Allah! If you consider that I did that for fear of you then please remove the rock. So Allah released them (removed the rock) and they came out of the cave. (Sahih Al-Bukhari, 4/3465 O.P. 671)

\section{Modesty}

Modesty is part of the faith (Al-Bukhari,. N.D. Part 1. Vol. 1, p. 13). Moreover; it is interesting to note that the Glorious Qur'an includes chaste people in the category of al-Mu'minun (The Believers):

"Successful indeed are the Believers - those who humble themselves in prayers; who avoid vain talk; who are active in giving zakah (compulsory charity); who guard their chastity except with those joined to them in the marriage bond "(Qur'an, 23: 16). hereunder:

Some of the Islamic guidelines which could assist Muslims to uphold sexual morality are discussed

\section{$1 \quad$ Early Marriage}

Prophet Muhammad (PBUH) while engaged in the process of advising young Muslims told them:

Young men, those of you who can support a wife should marry, for it keeps you from

looking at strange women and preserves your chastity, but those of you who cannot

marry should fast, for it is a means of cooling the sexual passion. (Al-Naysaburi,

N.D. Hadith no. 1. Vol. 3, p. 546)

\section{Lowering of the gaze}

The Glorious Qur'an instructs the believing men and women to lower their gaze and to safeguard their chastity. Shaykh Yusuf al-Qaradawi explains this instruction in the following manner:

What Islam prohibits in the sphere of sex includes looking at a member of the opposite sex with desire; for the eye is the key to the feelings, and the look is the messenger of desire, carrying the message of fornication or adultery (Al-Qaradawi, Yusuf. N.D. pp. 151-152)

It is primarily to protect his followers from being tempted to commit adultery or fornication. Prophet Muhammad (PBUH) said to Sayyiduna Ali: Ali, do not let the second look follow the first. The first is allowed, but not the second (Al-Sijistani, Abu Dawud Sulayman ibn al-As[ab. N.D. Hadith no. 2149. Part 2. Vol. 1, p. 246.) Prophet Muhammad (PBUH) even looking at the member of the opposite sex with lust and desire as tantamount to zina (adultery) of the eyes. The eyes also commit zina, and its zina is the (lustful) look (Ibid. Hadith no. 2152, pp. 246-247) At this juncture, let us consider the Biblical and Qur'anic commandments which pertain to adultery. The injunction of the Old Testament as enumerated in the Ten Commandments is: "Thou 
shalt not commit adultery". and that of the Glorious Qur'an is: (The Bible - The Revised Standard Version. Exodus 20:14)

"Do not come near to adultery. It is a shameful deed, an evil, opening the way to other evils" (Qur'an, 17: 32).

It is evident that the Old Testament only uses the imperative to caution against the actual engagement in the act of adultery, while the Glorious Qur'an warns against coming near to adultery. It is for this reason that the Glorious Qur'an further commands the believing women to cover themselves with a loose outer-garment whenever they go out in public, for this, would protect them from being molested (Qur'an, 33: 59). They are also cautioned not to talk invitingly as this may attract the attention of lustful men, (Qur'an, 33: 32) and not to walk in such a manner as to draw men's attention towards them (Qur'an, 24: 31). It must be noted though that these Qur'anic injunctions do not suggest that women on the whole are not to be trusted. Nay, these injunctions are meant to protect them from being victims of rape and other sexual crimes. In the western world, it is often boasted that women have been liberated for they can dress in any manner they so wish; take up any type of profession and intermingle freely with men. Is this in reality liberation? Those who design women's clothing design them with the aim of giving the women who wear them maximum sex appeal. In other words, western women are being exploited to dress in such a manner to make themselves sexually appealing to the general public (Noibi, 2004 and Niazi, 1976). Moreover, when women go out to earn a living, they become economically independent; causing them to think that there is no real need for them to get married. That is why we find that a substantial number of them are satisfied to be live in- partners without exchanging any form of marriage vows and without the church's blessing. Their conscience does not bother them that they are living in sin although all religions condemn sex outside marriage. Furthermore, their intermingling freely with men in night clubs does result in many social ills like wife swooping, adultery, fornication, teenage pregnancies, single parents and an increase in divorce cases.

The `Awrah

The [awrah] in legal terms implies the parts of the body that are to remain covered. Exposing such parts would be in contravention of the dictates of the Shari ah and deemed haram (impermissible). The 'awrah of a Muslim woman is explained by Prophet Muhammad (PBUH) in a Hadith addressed directly to Sayyidatuna Asma', the daughter of Sayyiduna Abu Bakr: After a girl attains the menstrual age (i.e., puberty) nothing should be seen of her except her face and hands (Sunan Abi Dawud, Hadith no. 2152, pp. 246-247). Even men are required by the Shari ah to clad themselves properly. Prophet Muhammad (PBUH) explained that the men should be covered at least from the navel to the knees. (Hanbal, Ahmad bin. N.D. Vol. 2, p. 187). Muslim men are, therefore, not permitted to wear conventional swimming trunks. If they are to participate in swimming activities, they have to ensure that they wear such shorts that would cover the area between the navel and the knees. In other words, there should be no indecent exposures of the bodies of both men and women in public, including the censure of using women as enticement in advertisements to sell goods or products of any sort. Moreover, Prophet Muhammad (PBUH) cursed the women who try to resemble men and the men who try to resemble women, either in clothing or manners. (Sahih al-Bukhari. Hadith no. 773. Vol. 7, p.513)

From this it can be inferred that unisex clothing has no place within the Islamic society. This injunction serves to prevent sexual perversions from creeping into the society.

\section{Punishments for Sexual Offences}

Illicit and same sex relations reflect irresponsibility and are categorized by the Shari ah as major crimes. The prescribed punishments, for example, for those who engage in illicit sexual intercourse are of a severe nature (Qur'an, 24:2) and are meant to serve as deterrents. In contrast, in the western world, there is tendency to disguise sexual crimes by referring to them in such a manner to make them appear dignified. For example, adultery is termed as extra marital relationship and a young male and woman (not united in marriage) who are going out together are said to be courting or dating.

Diseases that are spread through non marital sexual relations are considered among the major problems of the Western and many other parts of the world (Maududi, (1967) and Manji, 1992). The religion of Islam forbids sex out of wedlock and unnatural sexual relations and safeguards society from these disasters by encouraging marriage and conjugal community. Sexual intercourse is forbidden throughout the duration of a woman's menstrual period (Mandara, 2004 and Lemu, 2004). During this period secretions are infected with germs and an "open wound surface" (the denuded endometrium) favors infections. Unnatural methods of sexual intercourse carry high inflection risks. The rectal mucosa is extremely sensitive to infections. $40 \%$ of the AIDS cases in the United States are found in homosexual men which is a clear indication of this fact. The use of intravenous illicit drugs, genital lesions and men that have not been circumcised are among other risk factors for AIDS (Farouq, 2003 and Farhad, 2011). The prepuce acts as a natural reservoir for secretions and germs and facilitates infection. Other important dimension of infection protection is preserving ecological balances. The 
destruction of nature and the disorder of relations between creatures bring to order forgotten diseases from the past and bring forward new unknown diseases. Just as there is a balance between creatures, there is a balance that exists between chemical elements and molecules. Disrupting the natural conformation of foods and beverages by means of hormones and chemicals, feeding animals, that should be fed by plants and herbs, with animal based feed grain causes pathological protein diseases such as mad-cow disease (El Tigani, 2010 and Bhayat, 1997). Similar problems remind us of the importance of Qur'an's warnings to abide by these balances and guidelines.

\section{Homosexuality}

Human beings are capable of many forms of sexual expression, orientation and identification. The existence of such a variety again is not found in any other species and thus further demonstrates our uniqueness among God's creations. The potential for behavior, such as homosexuality, does not mean that its practice is lawful in the eyes of God (Bhayat, 2003 and Athar-Shahid, 2003). Therefore, individuals are expected to control themselves and not act on their desires if such action is contrary to the guidelines of Islam. Homosexuality, like other forms of sexual relations outside of heterosexual marriage, is thus prohibited (Al-Sheha, 2001 and Akbar, 1994).

In the Qur'an, it is mentioned that in the community of the Prophet Lut (AS) there were people whose behavior transcended Islamic law, and that there were men who had sexual relations with other men, and were consequently punished. "We also (sent) Lut: He said to his people 'Do ye commit lewdness such as no people in creation (ever) committed before you? For ye practice your lusts on men in preference to women: ye are indeed a people transgressing bounds'. And the answer of his people was no other than that they said: Turn them out of your town, surely they are a people who seek to purify (themselves)" (Surah7:80-82) "Would ye really approach men in your lusts rather than women? Nay, you are a people who act ignorantly!" (Surah 27:55) Indeed in contemporary times there has been significant debate and negotiation within major world religions regarding homosexuality. Numerous sociological theories have been formulated to explain homosexuality, which fall somewhere between two major schools of thought, namely essentialism and constructionism, which align with the rationalist dichotomy of 'nature' versus 'nurture'. The theory of essentialism describes homosexuality as a biological or physiological phenomenon, whereby the physical constitution or genetic makeup of an individual may predispose them to homosexuality. On the other hand, the theory of constructionism asserts that homosexuality can arise in response to a number of environmental influences, such as childhood, parenting, life experiences, and cultural phenomenon such as media or the openness of a society to diverse sexual orientations (Adeyinka, 1997 and Abdul'Ati, 1982).

The Qur'an and hadith are explicit regarding severe punishment by the State if a person is convicted of such a crime. However, in order for conviction to take place, the individuals must confess or be accused by at least four eyewitnesses of the act of actual intercourse. Obviously, the likelihood of these criteria being met is small which means that most couples who engage in unlawful acts will not be punished by the State. They will then deal with the consequences of their behavior in this life and will be accountable to God on the Day of Judgement. How He ultimately judges is known only to Him.

\section{Celibacy/Monasticism}

The Islamic point of view about the worldly good things is not negative, rather it says that we should appreciate them as the blessings of God. And Islam is, therefore, totally opposed to monasticism and celibacy. 'Uthman bin Maz'un was a close companion of the Prophet. One day his wife came to the Prophet and complained, "O the Messenger of God! 'Uthman fasts during the day and stands for prayers during the night." In other words, she meant to say that her husband was abstaining from sexual relations during the night as well as the day. The Prophet was so much angered with this that he did not even wait to put on his slippers. He came out with the slippers in his hands and went to 'Uthman's house. The Prophet found him praying. When 'Uthman finished his prayers and turned towards the Prophet, the latter said, "O 'Uthman! Allah did not send me for monasticism, rather He sent me with a simple and straight/shari'ah]. I fast, pray and also have intimate relations with my wife. So whosoever likes my tradition, then he should follow it; and marriage is one of my traditions. (Sahih al-Bukhari.) Since 'Uthman was already married, the word "marriage" in this hadith can only be applied to sexual relations.

In another incident, three women came to the Prophet and complained that their husbands were abstaining from meat, perfume and intimate relations with their wives. The Prophet quickly came to the mosque, went on the pulpit and said, "What has happened to some of my companions that they do not eat meat, they do not use perfume and they do not go to their women?! Whereas I eat meat, use perfume and go to my wives. Therefore whosoever dislikes my tradition, then he is not from me. (Sahih al-Bukhari.) Ibn Abu 'Umar quotes that Sikkin an-Nakha'i had devoted himself to prayers and abstinence from women and delicious food. Then he wrote a letter to Imam Ja'far as-Sadiq seeking clarification about his actions. The Imam wrote, "As for what you 
have said about abstaining from women, you surely know how many women the Prophet had! As for food, the Prophet used to eat meat and honey." (Sahih al-Bukhari.) The Imam is obviously condemning the holier-thanthou attitude of his companion.

Imam 'Ali narrates that some companions of the Prophet had vowed to abstain from sexual relations with their wives, from eating during the day and from sleeping during the night. Umm Salamah, the Prophet's wife, informed him about this group. The Prophet went out to his companions and said, "Do you abstain from women whereas I go to the women?! I eat during the day and sleep during the night! Whosoever dislikes my tradition, then he is not from me." After this speech, Allah revealed the following verse:

O you who believe! Do not forbid [for yourselves] the good things which Allah has permitted you; and do not exceed [the law] Allah does not like those who exceed [the law]. Therefore eat of the lawful and good things that Allah has provided you, and fear Allah in whom you believe. (5:87-8)

Read this verse carefully and see that firstly, it counts sex, food and sleep among "the lawful and good things which Allah has permitted you;" and secondly celibacy and abstinence is considered as "exceeding the law of God." After this verse was revealed, those companions came to the Prophet and said, "O Messenger of God! We have taken oath to abstain from those things." That is, how can we now break our oath of abstinence? Then Allah revealed the following verse "Allah will not call you [to account] for vain oaths... "(5:84) Again, note that an oath of celibacy or abstinence from the good and lawful things is considered by Islam as 'vain oaths!' (Sahih Muslim)

The discouraging of celibacy is not confined to men, even women have been discouraged from remaining single. Imam Ja'far as-Sadiq said, "The Prophet has forbidden the women to become ascetic and to prevent themselves from husbands." (Sahih Muslim) woman came to Imam Ja'far as-Sadiq and said, "May God bless you; I am an ascetic woman."

The Imam: "What does asceticism mean to you?" The woman: "It means that I will never marry."

The Imam: "Why?"

The woman: "By practicing asceticism, I want to acquire favor (of

God)."

The Imam: "Go away! If asceticism was a means of acquiring favor (of God), then Fatimah would have been more entitled to it than you because none can gain more favor [in the eyes of Allah] than her." (Sahih alBukhari) A similar incident is also narrated in relation to Imam Riza. The Prophet said, "The most low [in status] among your dead are the singles." (Sahih al-Bukhari) Imam Ja'far as-Sadiq says that a person came to my father. My father asked him, "Do you have a wife? " He said, "No. " My father said, "I would not prefer to have the world with all its riches while I sleep at night without a wife." (Sahih Muslim)

\section{Being faithful}

This is to be faithful to once wife or husband in marriage while he or she does the same. In this regards Islam considers men and women as being of the same essence who created from a single soul. The holy Qur'an Chapter (4:1-2) declares:

'O mankind, reverence your guardian Lord, who created you from a single person, created of like nature, his mate, and from this pair scattered (like seed) countless men and women. Reference Allah through whom you demand your mutual (rights) and reverence the wombs (that bore you! For Allah ever watch over you.

Definitely Allah has preordain marriage ties among you for certain purpose, that is, the production that leads to the spread of mankind of both sexes as the above Qur'anic verses indicates. He also demands of mankind to fear him and respect the womb kinship. Reproduction been one of the major objectives of marriage, the prophet (S.A.W) was quoted saying:

"Many wives that deliver (babies and give you love

From this hadith one can also see that love or affection is one of the qualities expected between the couples, which lead to faithfulness and abstinence from extra marital sex that could lead to contacting HIV. Allah, in the holy Qur'an emphasize the quality along with other vital ones, also Qur'an Chapter (30:21) Said: "It among his sign that he created for your spouse from among you so as to go to them for repose and establish affection and mercy between you"

Therefore, one should note that the objective in this verse is faithfulness to each other through repose, affection and mercy which are the real commenting factor of marriage couple with all the necessary fear of Allah which serves as a great barrier against HIV/AIDS

Islam also bans a woman to refuse her husband's request, he may be led to evil thoughts searching for 
unlawful satisfaction, or else, develops mental pressure. Such situations are detrimental both physically and mentally to marriage. In Islam, therefore insists on this issue as the Prophet is reported to have said

If' a man calls his wife to sleep with him and She does not respond, causing him to be angry With her, angels will (continue) to curse her until Morning (Abu Daud and Nisai)

Likewise, Islam applies the same towards the husband who must satisfy his wife's sexual desire in order to protect her against evil thoughts and actions as well. Allah says in the holy Qur'an as thus:

But when they have purified themselves ye may approach them in any manner, time, or Place ordained for you by Allah. For Allah loves those who keep themselves pure and clean

Also, Islam looks at the proper use of sex as an act of worship 'Ibadah'. A Muslim will be rewarded when he practice this act, as he is reward when he does any other acts of prescribed types of worship. This is in line with the hadith of the Prophet (SAW) in which he alluded to this concept as follows:

A Muslim who has an intercourse with his spouse will be rewarded for it. The companion asked Oh! Prophet of Allah! a person will be rewarded while satisfying his sexual need? The prophet replied" yes isn't 'it that he would be punished had he practiced sex illegally? The same applies if a Muslim practiced a lawful intercourse with his spouse. As such he would be rewarded (Muslim)

The only acceptable way for sexual satisfaction in Islam is a lawful marriage. The Prophet (SAW) also reported to have said: "The best among you is the one who is the best to his (wife) and I am best among of you to my (wife)" (Abu Daud)

In addition, Islam idealizes such a wife as the best woman. As the Prophet (SAW) describes such woman as follows. "(She is that woman)who please (her husband) When he looks at her, obeys him when he commands (instructions or requests) fulfills his demand and preserves his wealth" (An.nisai)

The Prophet (SAW) is also reported to have said concerning the same subject thus:

The best gain a Muslim acquires after (commitment to Islam is a beautiful wife

pleases him when he looks at her, obeys his command, protect his privacy when he is absent, and protect his wealth (Tirimidhi)

This means that Islam encourages the two partners to be faithful and good to each other

Furthermore, in other to promote goodness and faithfulness among the spouses, Islam therefore, encourages and places a great value for the fun between the two spouses. The Prophet (SAW) is reported to have said; “"

All the fun that man has in vain except for three items, shooting arrows,

discipline (training a Gorse and having fun with his wife. These three items are but truthful (or lawful) Means of fun (Ahmed)

In fact, Islam encourages best grooming for both spouses. Decent grooming promotes love and increase affection between spouses. The Prophet (SAW) reported to have said:

"Truly Allah is beautiful and He likes beauty"(Muslim)

Also, Ibn abbas (R.A.) is reported to have said that:

I try to look best to my wife as I like her to look best to me, I also do not like to demand all my rights on to her, as Allah's messenger (S.A.W) I am afraid she would also demand her full right unto me (in such a case I wouldn't be able to fulfill it for her. Similarly, Allah state in the holy Qur'an thus; "And woman shall have right similar to the right against them, according to what is equitable: But men have a degree (of advantage) over them and Allah is exalted in power wise" (Q 2:228)

In conclusion, Islam teaches self discipline and self control. It also differentiates between human being and animals, it's also teaches decency not to destroy ourselves with our own hands as indicate in the holy Qur'an chapter (2:195) "And do not throw yourselves into destruction."

\section{Conclusion}

In This Paper it was found that, Islam considers sex as one of the essential human needs that must be properly satisfied. It is a necessity of the human being that, it requires favourable consideration. Infact, Islam considers it as one of the requirements of life that should be properly and lawfully satisfied. Moreover, Islam does not treat it as a distasteful, filthy or heinous act of man. It also, considers "Zina" not only as a great sin but also as an act, which opens the gate for many other shameful acts, which destroys the very basis of the family, leads to quarrels, murders, ruins reputation/ properties and also spreads numerous diseases, both physical and spiritual. It is recommended that, Muslim should marry as early as they are able. Muslims should not fear 
poverty nor should they apprehend increase of family members as a result of marriage, and thus, because of that, stay away from marriage. Also, in Islam modesty is part of the faith and it revealed some of the Islamic guidelines which could assist Muslims to uphold sexual morality such as: early marriage, lowering of the gaze and to safeguard their chastity, proper dressing especially after a girl attains the menstrual age (i.e., puberty) nothing should be seen of her except her face and hands. There was also evidence that, Islam, therefore, is totally opposed to acts such as homosexual, monasticism and celibacy. Therefore, the Qur'an and Hadith are explicit regarding severe punishment if a person is convicted of such a crime.

\section{References}

[1]. Abu 'Abdullah Muhammad bin Ismail: Al -Jami al-Sahih (Sahih al-Bukhari, (Cairo) Volume 7, Book 2, Number 331

[2]. Abu Da'ud, Sulaiman bin al -Ash'ath al- Sijistanii (1372 A.H) : Sunan Abi Da'ud, Cairo,

[3]. Abdul'Ati,H.(1982); The Family Structure in Islam, Lagos, Islamic Publication Bureah, p, 33

[4]. Adeyinka A.B. (1997); Islam and sex; According to Qur'an and Hadith. Islamabad Pakistan, Da'wah Academy. Pp, 51 -53

[5]. Akbar, K.F. (1994) Family Planning and Islam. A Review Hamdard Islamicus Vo. XVII, No 3.

[6]. Alli Y.A. (1978): The Holy Qur'an, Text, Translation with Commentary. The Islamic centre, Washington

[7]. Al-Sheha, A. R. (2001): Islamic Perspective on Sex, Riyadhi, Saudi Arabia, Umm Amr.

[8]. Al- Tirmidhi, Muhammad bin Isa (1352A.H): Al-Jami' al-Sahih well known as Sunna al-Tirmidhi, Cairo

[9]. Athar-Shahid "Sex (2003): Education, Teenage Islam and Marriage" Muslim Youth and Sexuality of Education, Lagos: Fountain Media publications.

[10]. Bhayat, M. Z. (2003): "Sex Education: Islam versus West" Muslim Youth and Sexuality Education, Lagos: Fountain Media publication

[11]. Bhayat, M. Z. (1997) “The Islamic Etiquettes of Sexual Relations” Islam and Sex, Pakistan, Da'wah Academy

[12]. Doi, A.R (1982). Basis of Shariah (Islam law), Zaria, Gaskiya, Corporation Limited

[13]. Farouq, A. K. (2003) "The Sexuality of Education Curriculum for Nigerian Schools: An Overview" Muslim Youth and Sexuality of Education, Lagos, Fountain Media Publications

[14]. Lemu A. (2004) "Islamic View Point on Family Planning" Islam, Health and Muslim Women, Abuja, Fomwan, Publication Magazine, Lagos, Al-Ameen Publication pp31-44

[15]. Mandara M.U. (2004). Health and Da'wah" Islam, Health and Muslim women, Abuja, Fomwan publication.

[16]. Manji K.P. (1992); 'Family Panning in Islam' Knowledge issue No 314, p.11

[17]. Maududi, S.A. (1967); Birth Control its Social, Political Economic Moral and Religious Aspect, Delhi, Morkazi Maktaba Islamic Publishers. Pp, 72-78

[18]. Muslim bin al-Hujjaj bin Muslim al-Qushairi (1393A.H): Sahih Muslim, Cairo

[19]. Niazi, A.M. (1976); Modern Challenges to Muslim Families, Pakistan, Bazor Lahore. Pp, 45-49

[20]. Noibi, D. O. S. (2004): "Child-Marriage, Education and Social Responsibilities" Islam, Health and Muslim Women, Abuja: Fomwan Publications

[21]. Ogunlayi, Munirat (2003) Islam and HIV/AIDS “A paper presented at the $10^{\mathrm{TH}}$ Anniversary of Women's wing of Organization of Muslim Unity (O.M.U) Nigeria Akure -Branch Ondo State on $25^{\text {th }}$ Jan., 2003

[22]. Shahid A. (2003) Sex education Teenage pregnancy, sex in Islam and marriage in Muslim youths and sexually education, Lagos, Fountain Media publishers.

[23]. Sharubassy A. (1974) Islam and family planning, Vol 2., Beirut, International planned parent hood Federation.

[24]. Sulaiman, K.O. (2006): Islamic Position towards the HIV/AIDS prevention. National Association of the promotion of the studies in Religion, Education, Languages and General- Studies, Pp, 145-148

[25]. Yusuf Al-Qardawi. (1998); The Lawful and the Prohibited In Islam,. Lagos. A-Tawheed Publishing, Co, P.199 